\title{
Pre-service Physics Teachers' Recognition of Apparatuses Used in Mechanics and Electricity and Magnetism Experiments
}

\author{
Çağlar Gülçiçek, Uygar Kanli* \\ Department of Math and Science Education, Faculty of Education, Gazi University, Turkey
}

Copyright(C2018 by authors, all rights reserved. Authors agree that this article remains permanently open access under the terms of the Creative Commons Attribution License 4.0 International License

\begin{abstract}
Although lab activities play an important role in physics teaching, many of these activities do not attain the expected objectives. Many reasons can be advanced for this, such as a lack of apparatus/equipment in schools, limits to the lab time allocated, teachers' lack of knowledge and skills about lab-oriented teaching methods or the teachers' lack of self-confidence having a negative effect on lab teaching. All these reasons increase the risk that lab activities will not achieve their objectives. This study was conducted to determine how well pre-service physics teachers recognized and understood the functions of various apparatuses and pieces of equipment used in mechanics and electricity and magnetism labs. The survey method was used to measure the pre-service physics teachers' levels of recognition $(n=118)$. The Physics Lab Apparatuses Recognition Test (PLART), consisting of four stages for each item, was developed as a data collection tool. The results of the present study indicate that pre-service physics teachers did not recognize or understand the functions of the majority of apparatuses frequently used in mechanics and electricity and magnetism experiments.
\end{abstract}

Keywords Physics Lab Apparatus, Mechanics, Electricity and Magnetism, Pre-service Physics Teachers

\section{Introduction}

Lab activities are an important component of physics. The AAPT [1] has shaped the learning outcomes of university-level lab curriculum, focusing on the areas of constructing knowledge, modeling, designing experiments, developing technical and practical lab skills, analyzing and visualizing data and communicating physics. These areas have a rather broad focus in terms of the knowledge, skills and attitudes required. Physics as a discipline is an experimental science. However, considered from a didactic point of view, lab applications can also be regarded as a teaching strategy for understanding the structure, laws, models and concepts of physics [2]. The effects of lab applications on the learning process have provoked much thought and research $[3,4]$. Another engaging topic is what kind of lab applications are best for targeted learning outcomes. This question has led the researchers to studies of testing or comparing the effects of different lab applications. In the literature, various different lab applications have been described and investigated in various ways $[5,6,7,8]$.

On the other hand, the effects of the experiments, which are used to teach students scientific concepts, have only really been questioned in the last twenty years [9]. As van den Berg states, there are many unanswered questions about the efficiency of labs [10]. It is a mistake to assume that the time and resources allocated for labs are well used without evidence for this [11]. The numbers and complexity of the objectives aimed at indicate that there are high expectations about what lab work can achieve [9]. It is only possible to meet these expectations through a high degree of planning and effort. As van den Berg underlines, labs are not places where students can learn science automatically [10].

The abundance of learning outcomes clearly indicate that there are high expectations about what can be done in the lab. This may make it difficult for teachers to plan, conduct and evaluate experiments according to their learning outcomes. The quantity and quality of experiments designed by teachers are directly associated with teachers' experience, preparation, planning and course loads [12]. However, the failure to properly set the objectives of lab studies [10] or to plan experiments according to specific objectives [9] may decrease the efficiency of labs. A lack of apparatus/equipment in schools and limits on the time allocated for labs may also cause distress to teachers [13]. Another important concern 
is teachers' failures to design experiments that are suitable both to meet the objectives and for the students' levels [14]. Unsuitable or inadequate experiments [15] and cases where lab work is out of sequence with the theoretical courses in the curriculum [16] may also decrease efficiency. In addition, some teachers are not able to use lab-oriented teaching methods and techniques adequately [17]. Some teachers may also fail to recognize and use specific pieces of equipment in labs and may not know how to maintain or fix these apparatuses [17]. For example, some chemistry teachers could not correctly identify most of the apparatuses used frequently in their labs [18]. In another study, it was determined that most pre-service chemistry teachers could not properly identify lab apparatus and did not know its functions [19]. Teachers may forget the function of, and how to use, equipment which they do not use frequently [20]. According to the findings of Kocakülah and Savaş, the number of pre-service teachers who believe that they cannot design an experiment without any assistance is very high. Some of these teachers stated that they had not been trained well enough [14]. The same study emphasized pre-service teachers' lack of knowledge of the field and a lack of self-confidence [14]. Comparing the skills of teachers who had graduated from different programs, Bello [21] determined that M. Sc./M. Ed. teachers had better skills in using lab apparatus. With regard to the occupational experiences of teachers, it has been shown that the teachers who had less than two years' experience were weaker at using lab equipment [21]. Many other reasons can be stated that may have a negative effect on lab teaching. All these reasons increase the possibility that studying in the lab will not achieve the expected goals.

\section{Purpose of the Study}

Suppose that there are various DC batteries, ammeters, voltmeters, rheostats and conductor wires in your lab. Which experiments can you conduct using these pieces of equipment? You can conduct experiments on investigating resistors in series and parallel, verifying the Kirchhoff Rules, finding the resistance of a conductor, determining the emf and the internal resistance of a battery etc. It is like creating objects using different pieces of Lego. The more specific uses each piece has, the more functional the final product will be. However, to achieve this, the specific uses of each piece of Lego need to be well known. If this is the case, then one's creativity is triggered. What, then, are the basic technical skills that a teacher needs to conduct experiments? A hierarchical classification of technical skill levels by Fadzil and Saat [22] contributes significantly to answering this question (Figure 1).

The basic technical skill in this hierarchy is the skill of recognizing apparatuses/pieces of equipment and their functions. In order for a teacher to design and conduct the aforementioned experiments, she or he should first know what equipment is to be used and what it is to be used for.
On the other hand, this skill also gives the teacher the opportunity of compensating for any equipment that is not available in the labs using items available in the immediate environment.

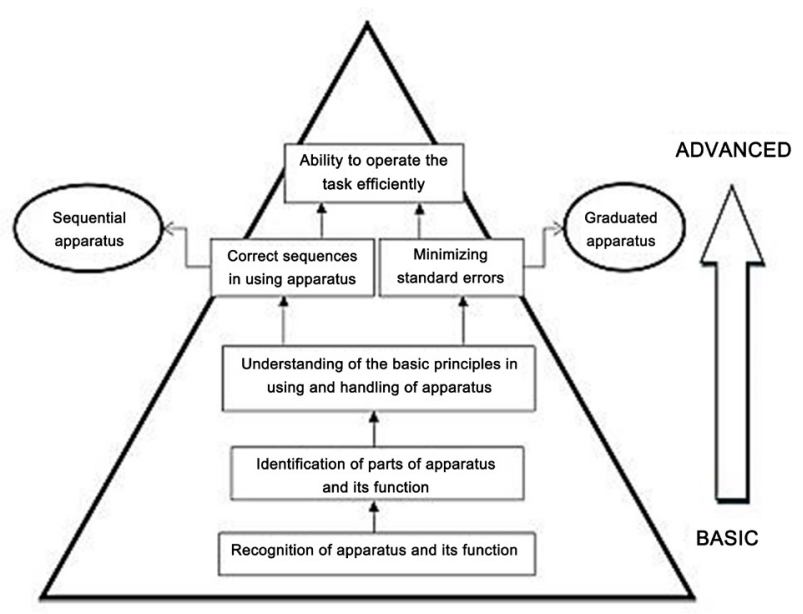

Figure 1. Five (5) levels hierarchy of technical skills [22]

For example, a teacher who knows the function of a rheostat will not be concerned whether it is available in the lab or not. She or he can develop a model that functions as a rheostat using conducting wires. This kind of basic skill is necessary in order to successfully transition into the abovementioned technical skills.

Some studies in the literature stress that it is necessary not only to be able to use apparatuses/equipment successfully, but also to have and to shape ideas [10, 23]. It is hard to disagree with this opinion. Here, however, the concern is primarily pre-service physics teachers' technical skills. This study was thus conducted to determine how well pre-service physics teachers recognize and understand the function of apparatuses/equipment used in mechanics and electricity and magnetism labs.

\section{Method}

The study was carried out using the survey method. As one of the quantitative research methods, the survey method is based on collecting information from a sample rather than from every member of a population. The method is used for the purpose of describing some aspects or characteristics (such as the abilities, opinions, attitudes, beliefs, and/or knowledge) of a population by asking questions, and the group members' answers to these questions constitute the data of the study [24]. Thus, to measure pre-service physics teachers' recognition of lab equipment and its functions the survey method was used.

\subsection{Population and Sample}

Convenience sampling was used to obtain a representative sample. A convenience sample corresponds 
to a group of individuals who are (conveniently) available for a study [24]. All of the participants were pre-service physics teachers who had graduated from a four-year physics teacher education program. Of these pre-service physics teachers, 118 participated in the study, which was approximately $10 \%$ of whole population.

\subsection{Structure of Physics Labs Apparatus Recognition Test (PLART)}

The Physics Labs Apparatus Recognition Test (PLART) is a diagnostic test rather than an achievement test. The PLART, consisting of four stages for each item, was used as a data collection tool. While answering each item in the test, the pre-service teachers were asked to write down the name of the piece of apparatus in the first stage and indicate their certainty about their answer to the first stage in the second stage. They were then asked to write down the function of the piece of apparatus in the third stage and indicate their certainty about their answer to the third stage in the fourth stage. The pre-service teachers answered the four-stage PLART test within approximately 20 minutes.

The PLART was developed focusing on experiments conducted at high school and university. Accordingly, apparatuses/pieces of equipment used in experiments on mechanics and electricity and magnetism in physics textbooks were listed, alongside experimental guidelines. In other words, the theoretical courses and laboratory applications in the curriculum of physics departments cover the usage and functions of these apparatuses/pieces of equipment. The pre-service teachers in their academic life encounter at least once with almost all of these apparatuses/pieces of equipment. In addition, as also taking the suggestions of eight academics who examined the list, 27 individual apparatuses/pieces of equipment used in mechanics and electricity and magnetism experiments were included in the PLART.

While pre-service teachers were taking the test, images of each piece of equipment viewed from different angles were displayed on a screen for 45 seconds.

\subsection{Data Analysis}

While scoring any item in the PLART, the answers to each stage of that item were coded as 1 and 0 . In the scoring, "correct" answers and the option "I am sure" correspond to 1 , whereas "incorrect" answers and the option "I am not sure" correspond to 0 . Accordingly, scorings with very different combinations for each item were obtained (e.g. 1, $1,1,1 ; 0,1,0,1$ etc.). These combinations were first evaluated according to the criteria adapted from the study by Kaltakç1 [25] (Table 1). Among these combinations, the ones meeting the criteria in Table 1 were all accepted as valid answers. On the other hand, combinations outside the criteria in Table 1 were all categorized as "I have no idea" (those who either indicated that they had no idea or left the question unanswered because they did not know).

While conducting these analyses, two researchers first coded three answer sheets selected randomly in order to increase consistency between codings. A consensus was reached after discussion. The researchers then coded another three answer sheets individually and another consensus was reached. At this stage, the consistency between coders was examined and was found to be $85 \%$. This result was sufficient because it proved that the coding was reliable [26].

As seen in Table 2 and Table 3, the percentage distributions of valid answers varied distinctly for each item. Accordingly, it was decided that it would be more meaningful to use frequency values while conducting a descriptive analysis for valid answers according to the criteria in Table 1.

Table 1. The criteria used in interpreting the results

\begin{tabular}{|c|c|c|c|c|c|}
\hline & \multicolumn{4}{|c|}{ Third and Fourth Tiers } \\
\hline & & $\begin{array}{l}\text { True and Sure } \\
\qquad(\mathrm{T} \& \mathrm{~S})\end{array}$ & $\begin{array}{l}\text { False and Sure } \\
\qquad(\mathrm{F} \& \mathrm{~S})\end{array}$ & $\begin{array}{l}\text { True and Not Sure } \\
\text { (T \& NS) }\end{array}$ & $\begin{array}{l}\text { False and } \\
\text { Not Sure } \\
(\mathrm{F} \& \mathrm{NS})\end{array}$ \\
\hline \multirow{4}{*}{ 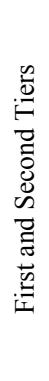 } & $\begin{array}{l}\text { True and Sure } \\
\qquad(\mathrm{T} \& \mathrm{~S})\end{array}$ & $\begin{array}{l}\text { Knows correct name and } \\
\text { function of the piece of } \\
\text { apparatus }\end{array}$ & $\begin{array}{l}\text { Knows correct name of } \\
\text { the piece of apparatus but } \\
\text { does not know its function }\end{array}$ & $\begin{array}{l}\text { Insufficient } \\
\text { knowledge }\end{array}$ & $\begin{array}{l}\text { Insufficient } \\
\text { knowledge }\end{array}$ \\
\hline & $\begin{array}{l}\text { False and Sure } \\
\qquad(F \& S)\end{array}$ & $\begin{array}{c}\text { Does not know the correct } \\
\text { name of the apparatus but } \\
\text { knows the correct } \\
\text { function }\end{array}$ & $\begin{array}{c}\text { Knows name and function } \\
\text { of the apparatus } \\
\text { incorrectly }\end{array}$ & $\begin{array}{l}\text { Insufficient } \\
\text { knowledge }\end{array}$ & $\begin{array}{l}\text { Insufficient } \\
\text { knowledge }\end{array}$ \\
\hline & $\begin{array}{l}\text { True and Not Sure } \\
\quad(T \& N S)\end{array}$ & $\begin{array}{l}\text { Insufficient } \\
\text { knowledge }\end{array}$ & $\begin{array}{l}\text { Insufficient } \\
\text { knowledge }\end{array}$ & $\begin{array}{l}\text { Insufficient } \\
\text { knowledge }\end{array}$ & $\begin{array}{l}\text { Insufficient } \\
\text { knowledge }\end{array}$ \\
\hline & $\begin{array}{c}\text { False and Not Sure } \\
\text { (F \& NS) }\end{array}$ & $\begin{array}{l}\text { Insufficient } \\
\text { knowledge }\end{array}$ & $\begin{array}{l}\text { Insufficient } \\
\text { knowledge }\end{array}$ & $\begin{array}{l}\text { Insufficient } \\
\text { knowledge }\end{array}$ & $\begin{array}{l}\text { Insufficient } \\
\text { knowledge }\end{array}$ \\
\hline
\end{tabular}


Table 2. Criteria for Apparatus Recognition Sub-Levels of the Pre-service Physics Teachers

\begin{tabular}{|c|l|}
\hline Sub-levels & \multicolumn{1}{c|}{ Explanation } \\
\hline Level 3 & $\begin{array}{l}\text { Knows the name and function of the apparatus/piece } \\
\text { of equipment. }\end{array}$ \\
\hline Level 2 & $\begin{array}{l}\text { Knows the function of the apparatus/piece of } \\
\text { equipment, but not its name. }\end{array}$ \\
\hline Level 1 & $\begin{array}{l}\text { Knows the name of the apparatus/piece of } \\
\text { equipment, but not its function. }\end{array}$ \\
\hline Level 0 & $\begin{array}{l}\text { Does not know the name and function of the } \\
\text { apparatus/piece of equipment. }\end{array}$ \\
\hline
\end{tabular}

In the second evaluation, the pre-service physics teachers' levels of recognition of each piece of apparatus were divided into four sub-levels from level 0 to level 3 (Table 2). Level 3 consists of the pre-service teachers who knew the names and functions of the pieces of apparatus. The level of the pre-service teachers who knew their functions is considered Level 2. The pre-service teachers who knew their names are included in Level 1. Level 0 consists of the following pre-service teachers: (a) those who had no idea, (b) those who were not sure of the answer, and (c) those who gave the wrong information/were mistaken. None of the pre-service teachers meeting the criteria (a), (b) or (c) knew the names or functions of the equipment. The results related to levels are shown in percentages in Tables 5a and 5b.

\section{Findings}

\subsection{Findings Concerning Apparatuses Used in Mechanics}

Among the pre-service physics teachers, 103 of them indicated that they had no idea about the centripetal force apparatus, 99 about the ticker timer, 86 about the gyroscope, 83 about micrometer, 72 about the water level apparatus, 71 about the collisions in two dimensions apparatus, 66 about the vacuum pump, 43 about the Atwood machine, 39 about the air table and 16 about the dynamometer and thus gave no answers about the names and functions of these.

According to other combinations obtained from the scoring, it was determined that among the pre-service teachers (Tables 3a, 3b and 3c):

Table 3a. Frequencies of Pre-service Physics Teachers' Answers about the Apparatuses Used in Mechanics

\begin{tabular}{|c|c|c|c|c|c|c|c|c|c|c|c|c|c|c|c|c|c|}
\hline & & \multicolumn{4}{|c|}{ Atwood Machine } & \multicolumn{4}{|c|}{ Dynamometer } & \multicolumn{4}{|c|}{ Ticker Timer } & \multicolumn{4}{|c|}{ Air Table } \\
\hline & & \multicolumn{4}{|c|}{ Third and Fourth Tiers } & \multicolumn{4}{|c|}{ Third and Fourth Tiers } & \multicolumn{4}{|c|}{ Third and Fourth Tiers } & \multicolumn{4}{|c|}{ Third and Fourth Tiers } \\
\hline & & $\begin{array}{c}\mathrm{T} \& \\
\mathrm{~S}\end{array}$ & $\begin{array}{c}\text { F \& } \\
\text { S }\end{array}$ & $\begin{array}{l}\text { T \& } \\
\text { NS }\end{array}$ & $\begin{array}{l}\text { F \& } \\
\text { NS }\end{array}$ & $\begin{array}{c}\mathrm{T} \& \\
\mathrm{~S}\end{array}$ & $\begin{array}{c}\text { F \& } \\
\text { S }\end{array}$ & $\begin{array}{l}\mathrm{T} \& \\
\mathrm{NS}\end{array}$ & $\begin{array}{l}\text { F \& } \\
\text { NS }\end{array}$ & $\begin{array}{c}\mathrm{T} \& \\
\mathrm{~S}\end{array}$ & $\begin{array}{c}\text { F \& } \\
\text { S }\end{array}$ & $\begin{array}{l}\text { T \& } \\
\text { NS }\end{array}$ & $\begin{array}{l}\text { F \& } \\
\text { NS }\end{array}$ & $\begin{array}{c}\mathrm{T} \& \\
\mathrm{~S}\end{array}$ & $\begin{array}{c}\text { F \& } \\
\text { S }\end{array}$ & $\begin{array}{l}\mathrm{T} \& \\
\mathrm{NS}\end{array}$ & $\begin{array}{l}\text { F \& } \\
\text { NS }\end{array}$ \\
\hline & & $\mathrm{f}$ & $\mathrm{f}$ & $\mathrm{f}$ & $\mathrm{F}$ & $\mathrm{f}$ & $\mathrm{f}$ & $\mathrm{f}$ & $\mathrm{f}$ & $\mathrm{f}$ & $\mathrm{f}$ & $\mathrm{f}$ & $\mathrm{f}$ & $\mathrm{f}$ & $\mathrm{f}$ & $\mathrm{f}$ & $\mathrm{F}$ \\
\hline \multirow{4}{*}{$\begin{array}{l}\text { First and } \\
\text { Second } \\
\text { Tiers }\end{array}$} & $\mathrm{T} \& \mathrm{~S}$ & 7 & 6 & 7 & 6 & 68 & 9 & 8 & 3 & 7 & - & 3 & - & 38 & 8 & 8 & - \\
\hline & $\mathrm{F} \& \mathrm{~S}$ & 1 & 18 & - & 5 & 2 & 2 & - & - & 2 & 1 & - & - & 7 & 6 & 2 & 1 \\
\hline & $\mathrm{T} \& \mathrm{NS}$ & 1 & - & 2 & - & 1 & - & 5 & - & 1 & - & - & - & 1 & - & 3 & - \\
\hline & $\mathrm{F} \& \mathrm{NS}$ & - & 1 & 1 & 11 & 1 & - & - & 2 & - & - & - & 4 & - & - & - & 3 \\
\hline \multicolumn{2}{|c|}{ Name Only } & \multicolumn{4}{|c|}{9} & \multicolumn{4}{|c|}{1} & \multicolumn{4}{|c|}{-} & \multicolumn{4}{|c|}{2} \\
\hline \multicolumn{2}{|c|}{ Function Only } & \multicolumn{4}{|c|}{-} & \multicolumn{4}{|c|}{-} & \multicolumn{4}{|c|}{1} & \multicolumn{4}{|c|}{-} \\
\hline \multicolumn{2}{|c|}{ No Idea } & \multicolumn{4}{|c|}{$43(36.5 \%)$} & \multicolumn{4}{|c|}{$16(13.6 \%)$} & \multicolumn{4}{|c|}{$99(83.9 \%)$} & \multicolumn{4}{|c|}{$39(33.1 \%)$} \\
\hline \multicolumn{2}{|c|}{ Valid Answers } & \multicolumn{4}{|c|}{$75(63.6 \%)$} & \multicolumn{4}{|c|}{$102(86.4 \%)$} & \multicolumn{4}{|c|}{$19(16.1 \%)$} & \multicolumn{4}{|c|}{$79(66.9 \%)$} \\
\hline
\end{tabular}

T: True F: False S: Sure NS: Not sure

Table 3b. Frequencies of Pre-service Physics Teachers' Answers about the Apparatuses Used in Mechanics

\begin{tabular}{|c|c|c|c|c|c|c|c|c|c|c|c|c|c|c|c|c|c|}
\hline & \multirow{2}{*}{\multicolumn{4}{|c|}{$\begin{array}{c}\text { Collisions in Two Dimen. } \\
\text { Apparatus } \\
\text { Third and Fourth Tiers }\end{array}$}} & \multicolumn{4}{|c|}{ Gyroscope } & \multicolumn{4}{|c|}{$\begin{array}{c}\text { Centripetal Force } \\
\text { Apparatus }\end{array}$} & \multicolumn{4}{|c|}{ Micrometer } \\
\hline & & & & & & \multicolumn{4}{|c|}{ Third and Fourth Tiers } & \multicolumn{4}{|c|}{ Third and Fourth Tiers } & \multicolumn{4}{|c|}{ Third and Fourth Tiers } \\
\hline & & $\begin{array}{l}\mathrm{T} \& \\
\mathrm{~S}\end{array}$ & $\begin{array}{c}\text { F \& } \\
\text { S }\end{array}$ & $\begin{array}{l}\text { T \& } \\
\text { NS }\end{array}$ & $\begin{array}{l}\text { F \& } \\
\text { NS }\end{array}$ & $\begin{array}{c}\mathrm{T} \& \\
\mathrm{~S}\end{array}$ & $\begin{array}{c}\mathrm{F} \& \\
\mathrm{~S}\end{array}$ & $\begin{array}{l}\text { T \& } \\
\text { NS }\end{array}$ & $\begin{array}{l}\text { F \& } \\
\text { NS }\end{array}$ & $\begin{array}{c}\mathrm{T} \& \\
\mathrm{~S}\end{array}$ & $\begin{array}{c}\mathrm{F} \& \\
\mathrm{~S}\end{array}$ & $\begin{array}{l}\text { T \& } \\
\text { NS }\end{array}$ & $\begin{array}{l}\text { F \& } \\
\text { NS }\end{array}$ & $\begin{array}{c}\mathrm{T} \& \\
\mathrm{~S}\end{array}$ & $\begin{array}{c}\mathrm{F} \& \\
\mathrm{~S}\end{array}$ & $\begin{array}{l}\text { T \& } \\
\text { NS }\end{array}$ & $\begin{array}{l}\text { F \& } \\
\text { NS }\end{array}$ \\
\hline & & $\mathrm{f}$ & $\mathrm{f}$ & $\mathrm{f}$ & $\mathrm{f}$ & $\mathrm{f}$ & $\mathrm{f}$ & $\mathrm{f}$ & $\mathrm{f}$ & $\mathrm{f}$ & $\mathrm{f}$ & $\mathrm{f}$ & $\mathrm{f}$ & $\mathrm{f}$ & $\mathrm{f}$ & $\mathrm{f}$ & $\mathrm{f}$ \\
\hline \multirow{4}{*}{$\begin{array}{l}\text { First and } \\
\text { Second } \\
\text { Tiers }\end{array}$} & $\mathrm{T} \& \mathrm{~S}$ & 3 & - & 1 & - & 5 & 3 & - & - & - & - & - & - & 5 & - & 1 & - \\
\hline & $\mathrm{F} \& \mathrm{~S}$ & 1 & 16 & - & 1 & 1 & 3 & - & 2 & 3 & 3 & - & 1 & 5 & 6 & - & - \\
\hline & T \&NS & - & - & - & - & 3 & - & 2 & 1 & 1 & - & 1 & - & 4 & - & 2 & 1 \\
\hline & F \&NS & - & 5 & 2 & 8 & 1 & 1 & - & 5 & - & - & - & 6 & 1 & - & - & 5 \\
\hline \multicolumn{2}{|c|}{ Name Only } & \multicolumn{4}{|c|}{1} & \multicolumn{4}{|c|}{1} & \multicolumn{4}{|c|}{-} & \multicolumn{4}{|c|}{ - } \\
\hline \multicolumn{2}{|c|}{ Function Only } & \multicolumn{4}{|c|}{9} & \multicolumn{4}{|c|}{4} & \multicolumn{4}{|c|}{-} & \multicolumn{4}{|c|}{5} \\
\hline \multicolumn{2}{|c|}{ No Idea } & \multicolumn{4}{|c|}{$71(60.2 \%)$} & \multicolumn{4}{|c|}{$86(72.9 \%)$} & \multicolumn{4}{|c|}{$103(87.3 \%)$} & \multicolumn{4}{|c|}{$83(70.4 \%)$} \\
\hline \multicolumn{2}{|c|}{ Valid Answers } & \multicolumn{4}{|c|}{$47(39.8 \%)$} & \multicolumn{4}{|c|}{$32(27.1 \%)$} & \multicolumn{4}{|c|}{$15(12.7 \%)$} & \multicolumn{4}{|c|}{$35(29.6 \%)$} \\
\hline
\end{tabular}


Table 3c. Frequencies of Pre-service Physics Teachers' Answers about the Apparatuses Used in Mechanics

\begin{tabular}{|c|c|c|c|c|c|c|c|c|c|}
\hline & & \multicolumn{4}{|c|}{ Water Level Apparatus } & \multicolumn{4}{|c|}{ Vacuum Pump } \\
\hline & & \multicolumn{4}{|c|}{ Third and Fourth Tiers } & \multicolumn{4}{|c|}{ Third and Fourth Tiers } \\
\hline & & $\mathrm{T} \& \mathrm{~S}$ & $F \& S$ & $\mathrm{~T} \& \mathrm{NS}$ & F \& NS & $\mathrm{T} \& \mathrm{~S}$ & $F \& S$ & $\mathrm{~T} \& \mathrm{NS}$ & F \& NS \\
\hline & & $\mathrm{f}$ & $\mathrm{f}$ & $\mathrm{f}$ & $\mathrm{f}$ & $\mathrm{f}$ & $\mathrm{F}$ & $\mathrm{f}$ & $\mathrm{f}$ \\
\hline \multirow{4}{*}{$\begin{array}{c}\text { First and } \\
\text { Second Tiers }\end{array}$} & $\mathrm{T} \& \mathrm{~S}$ & 7 & 3 & - & - & 30 & 1 & 3 & 1 \\
\hline & $F \& S$ & 5 & 13 & 1 & 2 & 2 & 2 & - & - \\
\hline & $\mathrm{T} \& \mathrm{NS}$ & 1 & - & 3 & - & 4 & - & 7 & - \\
\hline & F \&NS & - & - & 2 & 9 & - & - & - & 1 \\
\hline \multicolumn{2}{|c|}{ Name Only } & \multicolumn{4}{|c|}{-} & \multicolumn{4}{|c|}{-} \\
\hline \multicolumn{2}{|c|}{ Function Only } & \multicolumn{4}{|c|}{-} & \multicolumn{4}{|c|}{1} \\
\hline \multicolumn{2}{|c|}{ No Idea } & \multicolumn{4}{|c|}{$72(61.0 \%)$} & \multicolumn{4}{|c|}{$66(56.0 \%)$} \\
\hline \multicolumn{2}{|c|}{ Valid Answers } & \multicolumn{4}{|c|}{$46(39.0 \%)$} & \multicolumn{4}{|c|}{$52(44.0 \%)$} \\
\hline
\end{tabular}

- 68 of them knew the name and function of the dynamometer. This was the case for 38 of them for the air table, 30 for the vacuum pump, 7 for the Atwood machine, 7 for the ticker timer, 7 for the water level apparatus, 5 for the gyroscope, 5 for the micrometer and 3 for the collisions in two dimensions apparatus,

- None of them knew the name and function of the centripetal force apparatus

- 18 of them did not know the correct name and function of the Atwood machine. This was the case for 16 of them for the collisions in two dimensions apparatus, 13 for the water level apparatus, 6 for the air table, 6 for the micrometer, 3 for the centripetal force apparatus, 3 for the gyroscope, 2 for the vacuum pump, 2 for the dynamometer and 1 for the ticker timer,

- 9 of them knew the correct name of the dynamometer but not its correct function. This was the case for 8 of them for the air table, 6 for the Atwood machine, 3 for the gyroscope, 3 for the water level apparatus and 1 for the vacuum pump,

- 7 of them did not know the correct name of the air table but did know its correct function. This was the case for 5 of them for the micrometer, 5 for the water level apparatus, 3 for the centripetal force apparatus, 2 for the ticker timer, 2 for the dynamometer, 2 for the vacuum pump, 1 for the gyroscope, 1 for the collisions in two dimensions apparatus and 1 for the Atwood machine,

- 9 of them knew only the correct name of Atwood machine. This was the case for 2 of them for the air table, 1 for the dynamometer, 1 for the gyroscope and 1 for the collisions in two dimensions apparatus,

- 9 of them only knew the correct function of the collisions in two dimensions apparatus. This was the case for 5 of them for the micrometer, 4 for the gyroscope, 1 for the ticker timer and 1 for the vacuum pump,
- $\quad 34$ of them had insufficient information about the Atwood machine, 20 about the dynamometer, 20 about the water level apparatus, 18 about the air table, 17 about the collisions in two dimensions apparatus, 16 about the vacuum pump, 15 about the gyroscope, 13 about the micrometer, 9 about the centripetal force apparatus and 8 about the ticker timer.

\subsection{Findings Concerning Apparatus Used in Electricity and Magnetism}

Among the pre-service physics teachers, 103 of them indicated that they had no idea about the induction coil. This was the case for 102 of them about the rotary rheostat, 99 about the electric motor model, 93 about the torsion balance apparatus, 85 about the Helmholtz coil, 84 about the linear rheostat, 75 about the e/m apparatus, 67 about the transformer, 57 about the u-shaped iron core, 47 about the solenoid, 41 about the van de Graaff generator, 41 about the electroscope, 37 about the current balance apparatus, 37 about the electric bell, 17 about the milliamp meter, 12 about the low voltage power supply and 1 about the ammeter and thus they gave no explanations about the names and functions of these.

According to other combinations obtained from the scoring of the stages, it was determined that among the pre-service teachers (Tables $4 \mathrm{a}, 4 \mathrm{~b}, 4 \mathrm{c}, 4 \mathrm{~d}$ and $4 \mathrm{e}$ ):

- 101 of them knew the correct name and function of dynamometer ammeter. This was the case for 70 of them for the milliamp meter, 67 of them for the low voltage power supply, 45 for the electroscope, 24 for the van de Graaff generator, 22 for the electric bell, 21 for the linear rheostat, 12 for the transformer, 9 for the Helmholtz coil, 7 for the rotary rheostat, 6 for the u-shaped iron core, 6 for the solenoid, 5 for the electric motor model, 4 for the torsion balance apparatus, 1 for the induction coil, and 1 for the e/m apparatus, 
- None of them knew the correct name and function of the current balance apparatus,

- 59 of them did not know the correct name and function of the current balance apparatus. This was the case for 40 of them for the u-shaped iron core, 17 for the solenoid, 10 for the e/m apparatus, 8 for the transformer, 7 for the torsion balance apparatus, 5 for the electric bell, 4 for the Helmholtz coil, 4 for the linear rheostat, 3 for the induction coil, 3 for the ammeter, 2 for the electroscope, 2 for the milliamp meter, 2 for the van de Graaff generator and 1 for the electric motor model,

- 28 of them knew the name of the electric bell correctly but did not know its correct function. This was the case for 7 of them for the van de Graaff generator, 5 for the low voltage power supply, 2 for the electric motor model, 2 for the transformer, 2 for the solenoid, 2 for the electroscope, 1 for the torsion balance apparatus, 1 for the Helmholtz coil, 1 for the milliamp meter, 1 for the $\mathrm{u}$-shaped iron core and 1 for the ammeter,

- 28 of them did not know the correct name of the solenoid but did know its correct function. This was the case for 5 of them for the e/m apparatus, 4 for the current balance apparatus, 3 for the Helmholtz coil, 3 for the electroscope, 2 for the van de Graaff generator,
2 for the ammeter, 1 for the rotary rheostat, 1 for the torsion balance apparatus and 1 for the transformer,

- 15 of them only knew the correct name of van de Graaff generator. This was the case for 11 of them for the electric bell, 9 for the low voltage power supply, 5 for the milliamp meter, 4 for the transformer, 4 for the solenoid, 4 for the linear rheostat, 3 for the Helmholtz coil, 2 for the rotary rheostat, 1 for the induction coil, 1 for the electric motor model, 1 for the torsion balance apparatus, 1 for the e/m apparatus, 1 for the $\mathrm{u}$-shaped iron core and 1 for the electroscope,

- 6 of them only knew the correct function of the e/m apparatus. This was the case for 3 of them for the transformer, 2 for the induction coil, 1 for the van de Graaff generator, 1 for the low voltage power supply and 1 for the electroscope,

- 24 of them had insufficient information about low voltage power supply. This was the case for 23 of them for the electroscope, 23 for the milliamp meter, 23 for the van de Graaff generator, 21 for the transformer, 20 for the e/m apparatus, 18 for the current balance apparatus, 15 for the electric bell, 14 for the solenoid, 13 for the Helmholtz coil, 13 for the u-shaped iron core, 11 for the torsion balance apparatus, 10 for the electric motor model, 8 for the induction coil, 8 for the ammeter, 6 for the rotary rheostat and 5 for the linear rheostat.

Table 4a. Frequencies of Pre-Service Physics Teachers' Answers about the Apparatuses Used in Electricity-Magnetism

\begin{tabular}{|c|c|c|c|c|c|c|c|c|c|c|c|c|c|c|c|c|c|}
\hline & \multicolumn{4}{|c|}{ Ammeter } & \multicolumn{4}{|c|}{$\begin{array}{c}\text { Current Balance } \\
\text { Apparatus }\end{array}$} & \multicolumn{4}{|c|}{$\begin{array}{c}\text { Power Supply Low } \\
\text { Voltage }\end{array}$} & \multicolumn{4}{|c|}{$\begin{array}{l}\text { Torsion Balance } \\
\text { Apparatus }\end{array}$} \\
\hline & & \multicolumn{4}{|c|}{ Third and Fourth Tiers } & \multicolumn{4}{|c|}{ Third and Fourth Tiers } & \multicolumn{4}{|c|}{ Third and Fourth Tiers } & \multicolumn{4}{|c|}{ Third and Fourth Tiers } \\
\hline & & $\begin{array}{c}\mathrm{T} \& \\
\mathrm{~S}\end{array}$ & $\begin{array}{c}\text { F \& } \\
\text { S }\end{array}$ & $\begin{array}{l}\text { T\& } \\
\text { NS }\end{array}$ & $\begin{array}{l}\text { F \& } \\
\text { NS }\end{array}$ & $\begin{array}{c}\mathrm{T} \& \\
\mathrm{~S}\end{array}$ & $\begin{array}{c}\mathrm{F} \& \\
\mathrm{~S}\end{array}$ & $\begin{array}{l}\text { T \& } \\
\text { NS }\end{array}$ & $\begin{array}{l}\text { F \& } \\
\text { NS }\end{array}$ & $\begin{array}{c}\mathrm{T} \& \\
\mathrm{~S}\end{array}$ & $\begin{array}{c}\text { F \& } \\
\text { S }\end{array}$ & $\begin{array}{l}\mathrm{T} \& \\
\mathrm{NS}\end{array}$ & $\begin{array}{l}\text { F \& } \\
\text { NS }\end{array}$ & $\begin{array}{c}\mathrm{T} \& \\
\mathrm{~S}\end{array}$ & $\begin{array}{c}\mathrm{F} \& \\
\mathrm{~S}\end{array}$ & $\begin{array}{l}\mathrm{T} \& \\
\mathrm{NS}\end{array}$ & $\begin{array}{l}\text { F \& } \\
\text { NS }\end{array}$ \\
\hline & & $\mathrm{f}$ & $\mathrm{f}$ & $\mathrm{f}$ & $\mathrm{f}$ & $\mathrm{f}$ & $\mathrm{f}$ & $\mathrm{f}$ & $\mathrm{f}$ & $\mathrm{f}$ & $\mathrm{f}$ & $\mathrm{f}$ & $\mathrm{f}$ & $\mathrm{f}$ & $\mathrm{f}$ & $\mathrm{f}$ & $\mathrm{f}$ \\
\hline \multirow{4}{*}{$\begin{array}{c}\text { First and } \\
\text { Second } \\
\text { Tiers }\end{array}$} & $\mathrm{T} \& \mathrm{~S}$ & 101 & 1 & 6 & - & - & - & - & - & 67 & 5 & 9 & 7 & 4 & 1 & - & - \\
\hline & $F \& S$ & 2 & 3 & - & - & 4 & 59 & - & 7 & - & - & - & 1 & 1 & 7 & - & 3 \\
\hline & T \&NS & 2 & - & 2 & - & - & - & - & - & 1 & - & 6 & - & - & - & - & 1 \\
\hline & F \&NS & - & - & - & - & - & 2 & 1 & 8 & - & - & - & - & - & 3 & - & 4 \\
\hline \multicolumn{2}{|c|}{ Name Only } & \multicolumn{4}{|c|}{-} & \multicolumn{4}{|c|}{-} & \multicolumn{4}{|c|}{9} & \multicolumn{4}{|c|}{1} \\
\hline \multicolumn{2}{|c|}{ Function Only } & \multicolumn{4}{|c|}{-} & \multicolumn{4}{|c|}{-} & \multicolumn{4}{|c|}{1} & \multicolumn{4}{|c|}{-} \\
\hline \multicolumn{2}{|c|}{ No Idea } & \multicolumn{4}{|c|}{$1(0.9 \%)$} & \multicolumn{4}{|c|}{$37(31.3 \%)$} & \multicolumn{4}{|c|}{$12(10.2 \%)$} & \multicolumn{4}{|c|}{$93(78.8 \%)$} \\
\hline \multicolumn{2}{|c|}{ Valid Answers } & \multicolumn{4}{|c|}{$117(99.2 \%)$} & \multicolumn{4}{|c|}{$81(68.6 \%)$} & \multicolumn{4}{|c|}{$106(89.8 \%)$} & \multicolumn{4}{|c|}{$25(21.2 \%)$} \\
\hline
\end{tabular}

Table 4b. Frequencies of Pre-Service Physics Teachers' Answers about the Apparatuses Used in Electricity and Magnetism

\begin{tabular}{|c|c|c|c|c|c|c|c|c|c|c|c|c|c|c|c|c|c|}
\hline & \multirow{2}{*}{\multicolumn{4}{|c|}{$\begin{array}{l}\text { Iron Core U Shaped } \\
\text { Third and Fourth Tiers }\end{array}$}} & \multirow{2}{*}{\multicolumn{4}{|c|}{$\begin{array}{c}\text { Rotary Rheostat } \\
\text { Third and Fourth Tiers }\end{array}$}} & \multirow{2}{*}{\multicolumn{4}{|c|}{$\begin{array}{c}\text { e/m Apparatus } \\
\text { Third and Fourth Tiers }\end{array}$}} & \multirow{2}{*}{\multicolumn{4}{|c|}{$\begin{array}{l}\text { Electric Motor Model } \\
\text { Third and Fourth Tiers }\end{array}$}} \\
\hline & & & & & & & & & & & & & & & & & \\
\hline & & $\begin{array}{c}\mathrm{T} \& \\
\mathrm{~S}\end{array}$ & $\begin{array}{c}\mathrm{F} \& \\
\mathrm{~S}\end{array}$ & $\begin{array}{l}\mathrm{T} \& \\
\mathrm{NS}\end{array}$ & $\begin{array}{l}\text { F \& } \\
\text { NS }\end{array}$ & $\begin{array}{c}\mathrm{T} \& \\
\mathrm{~S}\end{array}$ & $\begin{array}{c}\mathrm{F} \& \\
\mathrm{~S}\end{array}$ & \begin{tabular}{|l|} 
T \& \\
NS \\
\end{tabular} & $\begin{array}{l}\text { F \& } \\
\text { NS }\end{array}$ & $\begin{array}{c}\mathrm{T} \& \\
\mathrm{~S}\end{array}$ & $\begin{array}{c}\mathrm{F} \& \\
\mathrm{~S}\end{array}$ & $\begin{array}{l}\mathrm{T} \& \\
\mathrm{NS}\end{array}$ & $\begin{array}{l}\text { F \& } \\
\text { NS }\end{array}$ & $\begin{array}{c}\mathrm{T} \& \\
\mathrm{~S}\end{array}$ & $\begin{array}{c}\mathrm{F} \& \\
\mathrm{~S}\end{array}$ & $\begin{array}{l}\mathrm{T} \& \\
\mathrm{NS}\end{array}$ & $\begin{array}{l}\text { F \& } \\
\text { NS }\end{array}$ \\
\hline & & $\mathrm{f}$ & $\mathrm{f}$ & $\mathrm{F}$ & $\mathrm{f}$ & $\mathrm{f}$ & $\mathrm{f}$ & $\mathrm{f}$ & $\mathrm{f}$ & $\mathrm{f}$ & $\mathrm{f}$ & f & $\mathrm{f}$ & f & $\mathrm{F}$ & $\mathrm{F}$ & $\mathrm{f}$ \\
\hline \multirow{4}{*}{$\begin{array}{c}\text { First and } \\
\text { Second } \\
\text { Tiers }\end{array}$} & $\mathrm{T} \& \mathrm{~S}$ & 6 & 1 & - & - & 7 & - & 1 & - & 1 & - & 1 & 1 & 5 & 2 & - & - \\
\hline & $F \& S$ & - & 40 & - & 3 & 1 & - & - & - & 5 & 10 & 2 & 2 & - & 1 & - & - \\
\hline & T \&NS & 1 & - & 1 & - & 1 & - & 1 & - & 2 & - & 2 & - & - & - & - & - \\
\hline & F \&NS & - & - & - & 8 & - & 1 & - & 2 & 2 & 2 & - & 6 & - & - & - & 10 \\
\hline \multicolumn{2}{|c|}{ Name Only } & \multicolumn{4}{|c|}{1} & \multicolumn{4}{|c|}{2} & \multicolumn{4}{|c|}{1} & \multicolumn{4}{|c|}{1} \\
\hline \multicolumn{2}{|c|}{ Function Only } & \multicolumn{4}{|c|}{-} & \multicolumn{4}{|c|}{-} & \multicolumn{4}{|c|}{6} & \multicolumn{4}{|c|}{-} \\
\hline \multicolumn{2}{|c|}{ No Idea } & \multicolumn{4}{|c|}{$57(48.3 \%)$} & \multicolumn{4}{|c|}{$102(86.4 \%)$} & \multicolumn{4}{|c|}{$75(63.5 \%)$} & \multicolumn{4}{|c|}{$99(83.9 \%)$} \\
\hline \multicolumn{2}{|c|}{ Valid Answers } & \multicolumn{4}{|c|}{$61(51.7 \%)$} & \multicolumn{4}{|c|}{$16(13.6 \%)$} & \multicolumn{4}{|c|}{$43(36.4 \%)$} & \multicolumn{4}{|c|}{$19(16.1 \%)$} \\
\hline
\end{tabular}


Pre-service Physics Teachers' Recognition of Apparatuses Used

in Mechanics and Electricity and Magnetism Experiments

Table 4c. Frequencies of Pre-Service Physics Teachers' Answers about the Apparatuses Used in Electricity and Magnetism

\begin{tabular}{|c|c|c|c|c|c|c|c|c|c|c|c|c|c|c|c|c|c|}
\hline & \multicolumn{4}{|c|}{ Electric Bell } & \multicolumn{4}{|c|}{ Electroscope } & \multicolumn{4}{|c|}{ Helmholtz Coil } & \multicolumn{4}{|c|}{ Induction Coil } \\
\hline & & \multicolumn{4}{|c|}{ Third and Fourth Tiers } & \multicolumn{4}{|c|}{ Third and Fourth Tiers } & \multicolumn{4}{|c|}{ Third and Fourth Tiers } & \multicolumn{4}{|c|}{ Third and Fourth Tiers } \\
\hline & & $\begin{array}{c}\mathrm{T} \& \\
\mathrm{~S}\end{array}$ & $\begin{array}{c}\text { F \& } \\
\text { S }\end{array}$ & $\begin{array}{l}\text { T\& } \\
\text { NS }\end{array}$ & $\begin{array}{l}\text { F \& } \\
\text { NS }\end{array}$ & $\begin{array}{l}\mathrm{T} \& \\
\mathrm{~S} \\
\end{array}$ & $\begin{array}{c}\text { F \& } \\
\text { S }\end{array}$ & $\begin{array}{l}\text { T\& } \\
\text { NS }\end{array}$ & $\begin{array}{l}\text { F \& } \\
\text { NS }\end{array}$ & $\begin{array}{c}\text { T \& } \\
\text { S }\end{array}$ & $\begin{array}{c}\text { F \& } \\
\text { S }\end{array}$ & $\begin{array}{l}\text { T \& } \\
\text { NS }\end{array}$ & $\begin{array}{l}\text { F \& } \\
\text { NS }\end{array}$ & $\begin{array}{c}\text { T \& } \\
\text { S }\end{array}$ & $\begin{array}{c}\mathrm{F} \& \\
\mathrm{~S}\end{array}$ & $\begin{array}{l}\text { T \& } \\
\text { NS }\end{array}$ & $\begin{array}{l}\text { F \& } \\
\text { NS }\end{array}$ \\
\hline & & $\mathrm{f}$ & $\mathrm{f}$ & $\mathrm{f}$ & $\mathrm{f}$ & $\mathrm{f}$ & $\mathrm{f}$ & $\mathrm{f}$ & $\mathrm{f}$ & $\mathrm{f}$ & $\mathrm{F}$ & $\mathrm{f}$ & $\mathrm{f}$ & $\mathrm{f}$ & $\mathrm{f}$ & $\mathrm{F}$ & $\mathrm{f}$ \\
\hline \multirow{4}{*}{$\begin{array}{c}\text { First and } \\
\text { Second } \\
\text { Tiers }\end{array}$} & $\mathrm{T} \& \mathrm{~S}$ & 22 & 28 & 3 & 4 & 45 & 2 & 9 & 1 & 9 & 1 & - & - & 1 & - & - & - \\
\hline & $\mathrm{F} \& \mathrm{~S}$ & - & 5 & 1 & 1 & 3 & 2 & 1 & - & 3 & 4 & - & 1 & - & 3 & - & - \\
\hline & $\mathrm{T} \& \mathrm{NS}$ & 2 & - & 3 & 1 & 4 & - & 4 & - & 2 & 1 & 1 & 2 & 1 & - & 3 & - \\
\hline & F \&NS & - & - & - & - & - & - & 1 & 3 & - & 1 & 1 & 4 & 1 & 1 & - & 2 \\
\hline \multicolumn{2}{|c|}{ Name Only } & \multicolumn{4}{|c|}{11} & \multicolumn{4}{|c|}{1} & \multicolumn{4}{|c|}{3} & \multicolumn{4}{|c|}{1} \\
\hline \multicolumn{2}{|c|}{ Function Only } & \multicolumn{4}{|c|}{-} & \multicolumn{4}{|c|}{1} & \multicolumn{4}{|c|}{-} & \multicolumn{4}{|c|}{2} \\
\hline \multicolumn{2}{|c|}{ No Idea } & \multicolumn{4}{|c|}{$37(31.3 \%)$} & \multicolumn{4}{|c|}{$41(34.8 \%)$} & \multicolumn{4}{|c|}{$85(72.1 \%)$} & \multicolumn{4}{|c|}{$103(87.3 \%)$} \\
\hline \multicolumn{2}{|c|}{ Valid Answers } & \multicolumn{4}{|c|}{$81(68.6 \%)$} & \multicolumn{4}{|c|}{77 (65.3\%) } & \multicolumn{4}{|c|}{$33(28 \%)$} & \multicolumn{4}{|c|}{$15(12.7 \%)$} \\
\hline
\end{tabular}

Table 4d. Frequencies of Pre-service Physics Teachers' Answers about the Apparatuses Used in Electricity-Magnetism

\begin{tabular}{|c|c|c|c|c|c|c|c|c|c|c|c|c|c|c|c|c|c|}
\hline & \multicolumn{4}{|c|}{ Milliamp meter } & \multicolumn{4}{|c|}{ van de Graaff Generator } & \multicolumn{4}{|c|}{ Linear Rheostat } & \multicolumn{4}{|c|}{ Solenoid } \\
\hline & & \multicolumn{4}{|c|}{ Third and Fourth Tiers } & \multicolumn{4}{|c|}{ Third and Fourth Tiers } & \multicolumn{4}{|c|}{ Third and Fourth Tiers } & \multicolumn{4}{|c|}{ Third and Fourth Tiers } \\
\hline & & $\begin{array}{c}\mathrm{T} \& \\
\mathrm{~S}\end{array}$ & $\begin{array}{c}\text { F \& } \\
\text { S }\end{array}$ & $\begin{array}{l}\text { T\& } \\
\text { NS }\end{array}$ & $\begin{array}{l}F \& \\
\text { NS }\end{array}$ & $\begin{array}{c}\mathrm{T} \& \\
\mathrm{~S}\end{array}$ & $\begin{array}{c}\mathrm{F} \& \\
\mathrm{~S}\end{array}$ & $\begin{array}{l}\text { T \& } \\
\text { NS }\end{array}$ & $\begin{array}{l}\text { F \& } \\
\text { NS }\end{array}$ & $\begin{array}{c}\mathrm{T} \& \\
\mathrm{~S}\end{array}$ & $\begin{array}{c}\text { F \& } \\
\text { S }\end{array}$ & $\begin{array}{l}\text { T \& } \\
\text { NS }\end{array}$ & $\begin{array}{l}F \& \\
\text { NS }\end{array}$ & $\begin{array}{c}\mathrm{T} \& \\
\mathrm{~S}\end{array}$ & $\begin{array}{c}F \& \\
S\end{array}$ & $\begin{array}{l}\text { T \& } \\
\text { NS }\end{array}$ & $\begin{array}{l}F \& \\
N S\end{array}$ \\
\hline & & $\mathrm{f}$ & $\mathrm{F}$ & $f$ & $\mathrm{f}$ & $\mathrm{f}$ & $\mathrm{f}$ & $\mathrm{f}$ & $\mathrm{f}$ & $\mathrm{f}$ & $\mathrm{F}$ & $\mathrm{f}$ & $\mathrm{f}$ & $\mathrm{f}$ & $\mathrm{f}$ & $\mathrm{f}$ & $f$ \\
\hline \multirow{4}{*}{$\begin{array}{c}\text { First and } \\
\text { Second } \\
\text { Tiers }\end{array}$} & $\mathrm{T} \& \mathrm{~S}$ & 70 & 1 & 9 & - & 24 & 7 & 7 & 5 & 21 & - & 2 & - & 6 & 2 & 1 & 2 \\
\hline & $\mathrm{F} \& \mathrm{~S}$ & - & 2 & - & - & 2 & 2 & 2 & - & - & 4 & - & 1 & 28 & 17 & - & 4 \\
\hline & $\mathrm{T} \& \mathrm{NS}$ & 2 & - & 12 & - & - & - & 6 & - & - & - & 1 & - & 1 & - & 1 & 1 \\
\hline & F \&NS & - & - & - & - & - & - & 1 & 2 & - & - & - & 1 & 2 & - & - & 2 \\
\hline \multicolumn{2}{|c|}{ Name Only } & \multicolumn{4}{|c|}{5} & \multicolumn{4}{|c|}{15} & \multicolumn{4}{|c|}{4} & \multicolumn{4}{|c|}{4} \\
\hline \multicolumn{2}{|c|}{ Function Only } & \multicolumn{4}{|c|}{-} & \multicolumn{4}{|c|}{1} & \multicolumn{4}{|c|}{-} & \multicolumn{4}{|c|}{-} \\
\hline \multicolumn{2}{|c|}{ No Idea } & \multicolumn{4}{|c|}{$17(14.4 \%)$} & \multicolumn{4}{|c|}{$44(37.2 \%)$} & \multicolumn{4}{|c|}{$84(71.2 \%)$} & \multicolumn{4}{|c|}{$47(39.8 \%)$} \\
\hline \multicolumn{2}{|c|}{ Valid Answers } & \multicolumn{4}{|c|}{$101(85.6 \%)$} & \multicolumn{4}{|c|}{$74(62.8 \%)$} & \multicolumn{4}{|c|}{$34(28.8 \%)$} & \multicolumn{4}{|c|}{$71(60.2 \%)$} \\
\hline
\end{tabular}

Table 4e. Descriptive Statistics about the Apparatuses Used in Electricity and Magnetism

\begin{tabular}{|c|c|c|c|c|c|}
\hline & & \multicolumn{4}{|c|}{ Transformer } \\
\hline & & \multicolumn{4}{|c|}{ Third and Fourth Tiers } \\
\hline & & $\mathrm{T} \& \mathrm{~S}$ & $\mathrm{~F} \& \mathrm{~S}$ & T \& NS & $\mathrm{F} \& \mathrm{NS}$ \\
\hline & & $\mathrm{f}$ & $\mathrm{f}$ & $\mathrm{f}$ & $\mathrm{f}$ \\
\hline \multirow{4}{*}{$\begin{array}{c}\text { First and } \\
\text { Second Tiers }\end{array}$} & $\mathrm{T} \& \mathrm{~S}$ & 12 & 2 & 5 & 1 \\
\hline & $\mathrm{F} \& \mathrm{~S}$ & 1 & 8 & - & 3 \\
\hline & T \&NS & - & - & 1 & - \\
\hline & F \&NS & - & - & - & 11 \\
\hline \multicolumn{2}{|c|}{ Name Only } & \multicolumn{4}{|c|}{4} \\
\hline \multicolumn{2}{|c|}{ Function Only } & \multicolumn{4}{|c|}{3} \\
\hline \multicolumn{2}{|c|}{ No Idea } & \multicolumn{4}{|c|}{$67(56.8 \%)$} \\
\hline \multicolumn{2}{|c|}{ Valid Answers } & \multicolumn{4}{|c|}{$51(43.2 \%)$} \\
\hline
\end{tabular}

T: True F: False S: Sure NS: Not sure




\subsection{Determining the Apparatus Recognition Sub-levels of the Pre-service Physics Teachers}

The percentage distribution of the pre-service teachers' levels according to the apparatuses/equipment used in mechanics is shown in the Table 5a. With the exception of the dynamometer and the air table, the majority of pre-service teachers recognized other apparatuses at level 0. The percentage of the pre-service teachers in level 3 for most of the apparatuses/equipment is below $6 \%$. Even the level 3 percentage of the centripetal force apparatus is $0 \%$.

Table 5a. Percentage Distribution of the Apparatus Recognition Sub-Levels of the Pre-service Physics Teachers (Mechanics)

\begin{tabular}{|c|c|c|c|c|}
\hline \multirow{2}{*}{ Mechanics } & \multicolumn{4}{|c|}{ Recognition sub-levels (\%) } \\
\cline { 2 - 5 } & L3 & L2 & L1 & L0 \\
\hline Dynamometer & 57.6 & 3.4 & 17.8 & 21.2 \\
\hline Air table & 32.2 & 6.8 & 15.3 & 45.8 \\
\hline Atwood machine & 5.9 & 1.7 & 23.7 & 68.6 \\
\hline Ticker timer & 5.9 & 3.4 & 2.5 & 88.1 \\
\hline Water level & 5.9 & 5.1 & 2.5 & 86.4 \\
\hline Vacuum pump & 5.9 & 1.7 & 23.7 & 68.6 \\
\hline Gyroscope & 4.2 & 7.6 & 3.4 & 84.7 \\
\hline Micrometer & 4.2 & 12.7 & 0.8 & 82.2 \\
\hline Collision in two dimen. & 2.5 & 8.5 & 1.7 & 87.3 \\
\hline Centripetal force & 0 & 3.4 & 0 & 96.6 \\
\hline Mean & 12.4 & 5.4 & 9.2 & 73.0 \\
\hline
\end{tabular}

Table 5b. Percentage Distribution of the Apparatus Recognition Sub-Levels of the Pre-service Physics Teachers (Electricity and Magnetism)

\begin{tabular}{|c|c|c|c|c|}
\hline \multirow{2}{*}{ Electric. \& Magnet. } & \multicolumn{4}{|c|}{ Recognition sub-levels (\%) } \\
\cline { 2 - 5 } & L3 & L2 & L1 & L0 \\
\hline Ampere-meter & 85,6 & 3,4 & 5,9 & 5,1 \\
\hline Miliampere-meter & 59,3 & 1,7 & 12,7 & 26,3 \\
\hline Low voltage pow. supply & 56,8 & 1,7 & 25,4 & 16,1 \\
\hline Electroscope & 38,1 & 6,8 & 11,0 & 44,1 \\
\hline Van de Graaff Generator & 20,3 & 2,5 & 28,8 & 48,3 \\
\hline Electric bell & 18,6 & 1,7 & 39,0 & 40,7 \\
\hline Linear rheostat & 17,8 & 0,0 & 5,1 & 77,1 \\
\hline Transformer & 10,2 & 3,4 & 10,2 & 76,3 \\
\hline Helmholtz Coil & 7,6 & 4,2 & 3,4 & 84,7 \\
\hline Rotary rheostat & 5,9 & 1,7 & 2,5 & 89,8 \\
\hline Iron core u shape & 5,1 & 0,8 & 1,7 & 92,4 \\
\hline Solenoid & 5,1 & 26,3 & 7,6 & 61,0 \\
\hline Electric motor model & 4,2 & 0,0 & 2,5 & 93,2 \\
\hline Torsion balance & 3,4 & 0,8 & 1,7 & 94,1 \\
\hline E/m & 0,8 & 12,7 & 2,5 & 83,9 \\
\hline Induction coil & 0,8 & 3,4 & 0,8 & 94,9 \\
\hline Current balance & 0,0 & 3,4 & 0,0 & 96,6 \\
\hline Mean & 20.0 & 4.4 & 9.5 & 66.2 \\
\hline
\end{tabular}

Similarly, the percentage distribution of the pre-service teachers' levels according to the apparatuses/equipment used in electricity and magnetism is shown in Table $5 \mathrm{~b}$. The ammeter has the lowest level 0 percentage. Although the level 3 percentages for low voltage power supply and milliamp meter exceeded $50 \%$, the percentages in level 0 are noteworthy for these apparatuses. Evaluating Table $5 \mathrm{~b}$ in general, it is clear that level 0 contains the most percentages. The percentages in level 3 are quite low for many apparatuses.

Considering the average percentages of the levels in Table $5 \mathrm{a}$ and $5 \mathrm{~b}$, it can be stated that the pre-service teachers have serious difficulties in recognizing the apparatuses/ equipment.

\section{Conclusions and Discussion}

Lab studies involve students in the process of learning and exploring through first hand experiences. Students are encouraged to participate in scientific activities, which include asking questions, offering solutions, making predictions, organizing data and explaining examples. These activities give students an idea about how scientists conduct their own studies. Lab studies are thus generally used so that students can develop attitudes toward science, scientific research methods, conceptual understanding and technical skills [27, 28]. Any form of lab study can have goals such as these. However, it is not generally possible to distinguish, formulate and teach these goals clearly [10]. To facilitate this, as emphasized by van den Berg, it is possible to separate labs into "concept labs", "research labs" and "instrument skill labs" at lower levels of science teaching or at the beginning of lab courses [10]. These labs can be more integrated at upper levels, while always setting particular priorities rather than trying to succeed in all objectives at once [10]. Technical skills are indispensable for lab studies. Even though the primary aim of lab studies is generally accepted as achieving basic skills [10], studies in the literature clearly emphasize that teachers and pre-service teachers often face various problems with the equipment used $[14,17,18,19,20,29$, 30, 31].

The study focuses on the skill of recognizing lab apparatuses and equipment and knowing their function. This skill is considered as the basic technical skill in the hierarchical classification by Fadzil and Saat [22]. Yet, the results of the study indicate that pre-service physics teachers did not recognize the majority of the apparatuses and equipment frequently used in mechanics and electricity and magnetism experiments and did not know their functions. The percentage of the pre-service teachers who had no idea at all about the apparatuses used in mechanics and their functions varied between $87.3 \%$ (centripetal force apparatus) and 13.6\% (dynamometer). The average percentage of those who had no idea what a piece of equipment was or was for is $57.5 \%$. While the dynamometer's name and function were best known $(\mathrm{f}=68)$, the Atwood machine was least known $(\mathrm{f}=18)$. Interestingly enough, the pre-service teachers described the Atwood machine only as a simple pulley system or a simple pendulum and stated that it is used for measuring the rotation of the world, work-energy conservation, weight/mass and examining balance or free fall movement. 
In addition, none of the pre-service teachers knew the correct name and function of the centripetal force apparatus. The average frequency of pre-service teachers who knew the apparatuses/equipment used in mechanics and their correct functions was $\bar{f}=17$, which is very low. This average frequency corresponds to $14 \%$ of the sample.

On the other hand, the percentage of the pre-service teachers who had no idea at all about the names and functions of apparatuses/equipment used in electricity and magnetism varied between $87.3 \%$ (induction coil) and $0.9 \%$ (ammeter). The percentage of pre-service teachers who had no idea was $50.1 \%$. While ammeter's name and function were best known $(\mathrm{f}=101)$, the current balance apparatus was least known $(\mathrm{f}=59)$. In addition, none of the pre-service teachers knew the correct name and function of the current balance apparatus. The pre-service teachers described the current balance apparatus as a "bobbin" or a "solenoid" or even as a "capacitor" and stated that it is used for examining the induction phenomenon, creating or measuring a magnetic field and examining the change of a magnetic field with the number of turns. Another apparatus incorrectly identified by the pre-service teachers was the $\mathrm{u}$-shaped iron core $(\mathrm{f}=40)$. The pre-service teachers usually described this apparatus as a magnet and state that it is used for creating a magnetic field, determining magnetic poles and pulling substances like iron, nickel and cobalt. The average frequency of the pre-service teachers who knew the apparatuses/equipment used in electricity-magnetism and their correct functions was $\bar{f}=23,6$, which is very low. This average frequency corresponds to $20 \%$ of the sample.

The results show that the pre-service teachers were mostly in level 0 in terms of the recognition sub-levels. The percentage corresponding to level 3 knowledge of the 17 apparatuses was below 10\%. The level 3 percentages for the centripetal force and current balance apparatuses were zero. The level 3 percentages for only four apparatuses (dynamometer, low voltage power supply and milliamp meter and ammeter) exceeded 50\%.

There is a similarity between the results of this study and the results of prior studies examining the competency of pre- and in-service teachers in using lab tools in science teaching $[15,17,18,19,20]$. The results of this study are important because they reveal that a crucial aspect of science teachers' professional competency to conduct experiments is their motivation for experimentation [15]. Furthermore, teachers' experimental skills play a crucial role in enabling students to acquire science skills. [32]. On the other hand, because of teachers' limited knowledge of commonly used laboratory apparatus, many of the practical activities expected from learners/students may not be attended to, as the main facilitators lack the competence. In other words, the goals of teaching science in the labs are not effectively achieved [18]. Trna et. al (2012) underline the necessity of including the technique of using science equipment when training teachers to use science experiments. According to Fadzil and Saat [22] the basis of lab skills is the ability of recognizing apparatuses and pieces of equipment and their functions.

\section{Recommendations}

The results of this study show that pre-service physics teachers did not recognize the majority of apparatuses/equipment frequently used in mechanics and electricity and magnetism experiments and did not know their functions. The results of this study are thought-provoking and generate the need for further investigation. Examining the relevant literature, it is seen that there may be several reasons that these results were found:

i Pre-service teachers may forget the function of equipment which they do not use very frequently in their undergraduate programs [20].

ii The type of training received by pre-service teachers during their undergraduate program determines their ability to manage the teaching-learning process [21]. In Europe, there are different paths to becoming a physics teacher [33]. One of these is for physics teacher candidates to complete a program, which includes lectures about learning and teaching methods only after they have finished their lectures related to physics. A different path is for physics teacher-candidates to take these courses together [34].

In the light of these facts, the following recommendations are made:

(a) Pre-service physics teachers should attend in-service training programs related to lab skills and techniques before they become physics teachers.

(b) In the final year of undergraduate teacher-training programs, effective measures should be taken to review the prospective teachers' lab skills and techniques.

\section{REFERENCES}

[1] AAPT, (2014). Recommendations for the Undergraduate Physics Laboratory Curriculum, Report prepared by a Subcommittee of the AAPT Committee on Laboratories Endorsed by the AAPT Executive Board November 10, 2014. A Publication of the American Association of Physics Teachers.

[2] Sassi, E. and Vicentini, M. (2008). Aims and Strategies of Laboratory Work. In Vicentini, M. and Sassi. E. (Eeds.) Connecting Research in Physics Education with Teacher Education. I.C.P.E. Book.

[3] Kruglak, H. (1955). Measurement of Laboratory Achievement. Part III. Paper-Pencil Analogs of Laboratory Performance Tests, American Journal of Physics 23, 82 (1955); doi: 10.1119/1.1933904. 
[4] Holmes, N. G., Olsen, J, Thomas, J. L. and Wieman, C. E. (2017). Value added or misattributed? A multi-institution study on the educational benefit of labs for reinforcing physics content, Phys. Rev. Phys. Educ. Res. 13, 010129. doi.:10.1103/ PhysRevPhysEducRes.13.010129.

[5] Azar, A. (2010). A comparison of the effects of two physics laboratory applications with different approaches on student physics achievement. Energy Education Science and Technology Part B-Social and Educational Studies, 2(3-4), 161-185.

[6] Kanli, U. and Yagbasan, R. (2008). The Efficacy of the 7E Learning Cycle Model Based on Laboratory Approach on Development of Students' Science Process Skills. Gazi Uni. Journal of Gazi Educational Faculty. 28(1), 91-125.

[7] Kohnle, A., Brown, T., Rae, C. F. and Sinclair, B. D. (2012). Problem-based labs and group projects in an introductory university physics course. Physics Education, 47(4), 476-481.

[8] Russell, C.B., Weaver, G.C. (2011). A comparative study of traditional, inquiry-based, and research-based laboratory curricula: impacts on understanding of the nature of science. Chem. Educ. Res. Pract. 12, 57-67.

[9] Havlíček, K. (2015). Experiments in Physics Education: What do Students Remember? WDS'15 Proceedings of Contributed Papers Physics, 144-148.

[10] Van den Berg, E. (2009). The PCK of teaching in the laboratory: Turning manipulation of equipment into manipulation of ideas. In: O. de Jong and L. Halim (eds): Teachers' Professional Knowledge in Science and Mathematics Education: Views from Malaysia and Abroad. Publisher: Faculty of Education, Universiti Kebangsaan Malaysia, ISBN: 978-983-2267-07-2, p85-110.

[11] Wieman, C. and Holmes, N. G. (2015). Measuring the impact of an instructional laboratory on the learning of introductory physics. American Journal of Physics, 83 (11), 972-978.http://dx.doi.org/10.1119/1.4931717

[12] Okono, E.O., Sati, L.P. and Awuor, F. M. (2015). Experimental Approach as a Methodology in Teaching Physics in Secondary Schools. International Journal of Academic Research in Business and Social Sciences, Vol. 5, No. 6, 457-468. DOI.: 10.6007/IJARBSS/v5-i6/1011

[13] Demir, S., Böyük, U. and Koç, A. (2011). Views of Science and Technology Teachers on Laboratory Conditions and Use of Laboratory with Their Tendencies to Follow Technological Innovations. Mersin University Journal of the Faculty of Education. 7(2), 66-79.

[14] Kocakülah, A. and Savaş, E. (2011). Prospective Primary Science Teachers' Views about the Process of Designing and Practising Experiments. Ondokuz Mayis University Journal of Education Faculty. 30 (1), 1-28

[15] Trna, J. (2012). How to motivate science teachers to use science experiments. Journal of Systemics, Cybernetics and Informatics, 10(5), 33-35.

[16] Thomas, G. P., Meldrum, A. and Beamish, J. (2017). Transforming the Learning Environment of Undergraduate Physics Laboratories to Enhance Physics Inquiry Processes, Scientia in Educatione 8 (Special Issue), p. 276-284, ISSN 1804-7106.
[17] Böyük U., Demir, S. and Erol, M. (2010). Fen ve teknolojileri dersi öğretmenlerinin laboratuar çalışmalarına yönelik görüşlerinin farklı değişkenlere göre incelenmesi. TUBAV Bilim Dergisi, 3(4), 342-349.

[18] Ibe, J.O., Adah, S.A. and Ihejiamaizu, C.C. (2013). Assessment of Secondary School Chemistry teachers' quality through identification and uses of laboratory apparatus in cross River State, Nigeria. Journal of Education and Practice, 4(5), 135-141

[19] Bektas, O., Tuysuz, M., Kirbulut, Z.D. and Cetin-Dindar, A. (2011) Pre-service chemistry teachers' knowledge regarding laboratory equipment and and their functions, Third World Conference on Educational Sciences (WCES), Istanbul, Procedia-Social and Behavioral Sciences 15, 510-514. doi:10.1016/j.sbspro.2011.03.132

[20] Çıldır, S. (2012). The Preservice Physics Teachers 'Opinions About The Using of laboratory Equipment And The Determination Of Their Abilities To Design Experiments, Electronic Journal of Social Sciences, 11(42), 93-102, ISSN:1304-0278

[21] Bello, S. (2015). Effect of some teacher factors on the conduct of effective biology practical lesson, Global Advanced Research Journal of Educational Research and Review (ISSN: 2315-5132) Vol. 4(3) pp. 048-054.

[22] Fadzil, H. M. and Saat, R. M. (2017).Exploring Students' Acquisition of Manipulative Skills during Science Practical Work, EURASIA J. Math. Sci Tech. Ed., 13(8):45914607,DOI.:https://doi.org/10.12973/eurasia.2017.00953a

[23] Bell, P. (2004). The school science laboratory: Considerations of learning, technology, and scientific practice, Paper prepared for the meeting: High School Science Laboratories: Role and Vision, National Academy of Sciences.

[24] Fraenkel, J. R., Wallen, N. E. and Hyun, H. H. (2012). How to design and evaluate research in education (8th ed.). New York, NY: McGraw-Hill.

[25] Kaltakç1, D. (2012). Development And Application of a Four-Tier Test to Assess Pre-Service Physics Teacherse Misconceptions About Geometrical Optics. A Thesis Submitted to the Graduate School of Natural and Applied Sciences of METU, Ankara, Turkey.

[26] Boeije, H. (2002). A purposeful approach to the constant comparative method in the analysis of qualitative interviews. Quality and Quantity, 36, 391-409.

[27] Chiappetta, E. L. \& Koballa, T. R. (2002). Science instruction in the middle and secondary schools, Upper Saddle River, NJ: Merrill/Prentice Hall.

[28] Hofstein, A. and Lunetta, V. N. (1982). The Role of Laboratory in Science Teaching: Neglected Aspects of Research. Review of Educational Research 52(2): 201217.

[29] Ekici, F., Ekici, E. and Taşkın, S., (2002), Fen Laboratuarlarının İçinde Bulunduğu Durum, V. Fen Bilimleri ve Matematik Eğitimi Kongresi, 16-17 Eylül 2002, ODTU, Ankara.

[30] Harman, G. (2012). Analysing of the prospective elementary teachers' informations abouth laboratory equipments Used in Science and Technology Teaching. Journal of 
Educational and Instructional Studies in the World, 2(1), 122-127.

[31] Temiz, B.K. and Kanl1, U. (2005). The Identification of First-Year Undergraduate Students' Understanding on the Basic Physics Laboratory Equipments. Journal of National Education, 33(168), 188-201.

[32] Trna J., Trnová, E. \& Vaculová, I. (2010). Developing skills in learning and teaching science, In Contemporary science educational research: Learning and assessment. A collection of papers presented at ESERA 2009 conference. Ankara (Turkey): ESERA, 2010. pp. 165-172.

[33] Sauer, P. U. (2011) Strategies for physics teacher education in Europe STEPS TWO Forum Cyprus pp 2830.http://itp.uni-hannover.de/ sauer/Cyprus2011/cyprus201 1.pdf)

[34] Gülçiçek, Ç. and Damlı, V. (2016). An issue encountered in solving problems in electricity and magnetism: curvilinear coordinates. European Journal of Physics, vol.37(6), 1-21, doi: 10.1088/0143-0807/37/6/065704 